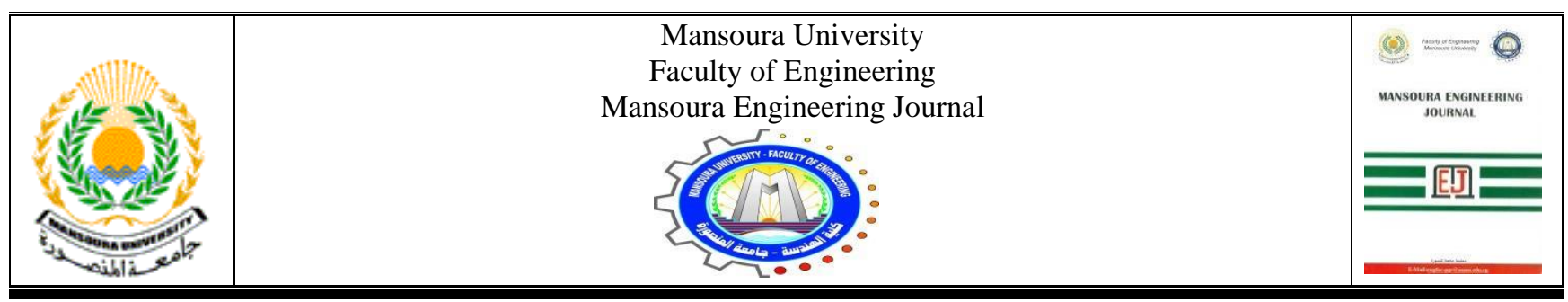

\title{
An Improved Particle Swarm Optimization Algorithm for Maximum Power Point Tracking Of Photovoltaic Cells in Normal and Under Partial Shading Conditions
}

\author{
Hend Samir Saad, Mohamed S. M. ElKsas, Sabry F. Saraya and Mohamed M. Abdelsalam
}

\author{
KEYWORDS: \\ Maximum Power Point \\ Tracking, Photovoltaic \\ cell, Particle Swarm \\ Optimization, Partial \\ shading
}

\begin{abstract}
Because of the world's acute energy crisis, the need for renewable energy sources is increasing today. In recent years, Standalone photovoltaic systems have been widely used in remote regions, following the growth of the photovoltaic cell industry. The key features of the systems of photovoltaic (PV) used to ingather solar energy while reducing the gas emissions of the greenhouse, maintenance costs are low, reduced site-related restrictions as a mechanical noise reduction due to no moving parts. Nevertheless, Photovoltaic systems are suffering from comparatively poor conversion efficiency. Hence, a PV system needs maximum power point tracking (MPPT) of the solar array. Several factors affect the maximum resulted power as nonlinear behavior of PV systems, temperature and the level of solar radiation that complicate monitoring of the maximum power point (MPP). This paper represents an evolutionary optimization algorithm using improved particle swarm optimization (PSO) technique for MPPT. The proposed technique has achieved high power in the conditions of partial shading rather than the conventional (PSO). The results of the simulation showed that the strategy could be reliable in monitoring the global MPPT in PV systems.
\end{abstract}

Received: (01 October, 2020) - Revised: (27 January, 2021) - Accepted: (3 February, 2021)

Corresponding Author: Hend Samir Saad Samir, M.SC Student at the Department of Computers Engineering and Control Systems, Faculty of Engineering - Mansoura University - (E-mail: hend.samir1@gmail.com).

Mohamed S. M. ElKsas, Associate professor at the Department of Computers Engineering and Control Systems, Faculty of Engineering Mansoura University. Currently in Delta University -(E-mail: msmksasy@gmail.com)

Sabry F. Saraya, Associate professor at the Department of Computers Engineering and Control Systems, Faculty of Engineering - Mansoura University -(E-mail: drsfsaraya@mans.edu.eg)

Mohamed M. Abdelsalam, Assistant professor at the Department of Computers Engineering and Control Systems, Faculty of Engineering Mansoura University -(E-mail: mohmoawed@yahoo.com)

\section{INTRODUCTION}

$\mathrm{T}$ $\mathrm{HE}$ massive use of fossil fuels in recent years have resulted in significant environmental pollution, rendering renewable energy sources a more attractive choice for producing electricity because of their inexhaustibility and environmentally friendly nature [1]. Solar energy is considered as: 1) one of the most important renewable energy sources and has been widely used in the generation of photovoltaic energy, 2) A better alternative for conventional energy, 3 ) it is one of the finest green energy choices among the available renewable energy resources, 4) it played a vital role in meeting the need for electricity in the last decades [2]. Photovoltaic (PV) systems are used to transform solar energy into electricity. The resulted power from this 
transformation depends on the ambient conditions such as ambient temperature, solar radiation intensity and load impedance. Therefore, the system may have several levels of output power or what is called "several output power point". The objective of the controller system is to obtain the maximum power point (MPP) in order to operate the loads. But, with different ambient and shading conditions, the maximum power point will be changed and shifted according to the electrical characteristics of the PV cells as will be described. So, the new aim of the controller system is to track the maximum power point or what is called "Maximum Power Point Tracking".

Several methods of MPPT have been suggested for the PV system to provide its maximum power [3]. Under non-shading conditions, the $\mathrm{P}-\mathrm{V}$ curve has only one MPP. Thus, conventional algorithms such as open circuit voltage (OCV) [4], perturbation and observation $(\mathrm{P \& O})$ [5] or extremum seeking control (ESC) [6] , short circuit current (SCC) [7], can easily extract the available maximum power from the PV array. However, in case of partial shading conditions, the P-V curve has several peaks. So, conventional algorithms suffer extraction of global maximum power point (GMPP) between local points, thus reducing the overall performance of the PV system [8].

The non-conventional algorithms such as Particle Swarm Optimization [9], Grey Wolf Optimization [10], Ant Colony Optimization [11] and Artificial Bee Colony [12] that inspired by findings of Darwin related to the growth of the biological kinds [13], have acquired much attention because of their ensured convergence towards the global peak. Certainly, the ability to handle multi-peaks that found on the (powervoltage) P-V curve and convergence speed are among its most advantages [14].

PSO was suggested by Kennedy and Eberhart as an alternative technique to the Genetic Algorithms (GAs) that inspired by the bird swarms' social behavior [15]. It begins with a random solution, finds an optimum solution through iterations, and estimates the solution's quality through fitness. The PSO algorithm is best suited for searching the global optimum. Furthermore, the PSO algorithm has a simple principle, high precision tracing and fast convergence.

The variance between the conventional methods and PSO algorithm is that with the PSO algorithm, the duty cycle update is based on the velocity of the particles, which is not fixed. Whereas when other methods are used, the duty cycle is perturbed by a constant value. This results in oscillations that occur in a steady state around the MPP [16].

Many studies have attempted to resolve the global MPP tracking under partial shading condition (PSC) by using various optimization methods [17-23]. A summary of their contributions is shown in Table 1. In [17], they proposed a hybrid algorithm to improve the tracking efficiency based on
Ant Colony Optimization (ACO) and local search capability of the Perturbation and Observation (P\&O) method. The objective is to yield faster and efficient convergence. Teaching Learning Based Optimization (TLBO) and Mine Blast Algorithm (MBO) are used to capture the GMPP for the systems under partial shading conditions [18, 19]. The algorithms have been evaluated in different PSC situations, such as non-uniform and uniform patterns with different global MPP positions. For fast tracking of the GMPP without oscillations, the authors implemented a hybrid algorithm of Whale Optimization (WO) with Differential Evolution (DE) [20]. Another study [21], they introduced the integration between Jaya and Differential Evolution (DE). Simulation work was used to test the proposed technique. The results showed that it tracked GMPP with sufficient accuracy for various studied cases. In order to identify the GMPP, a shuffled frog leap algorithm (SFLA) was performed. SFLA process results were compared with $\mathrm{PSO}$ and $\mathrm{P} \& \mathrm{O}$ algorithms. MATLAB/SIMULINK was used to implement the PV system [22]. A MPPT method with reduced steady-state oscillation based on a two-stage PSO technique was suggested by [23]. A hybrid shuffled frog leaping technique (SFLA)-PSO (PSOSFLA) algorithm to ensure that the global extremum was searched rapidly and accurately. In addition, an adaptive velocity factor was added to increase the speed of convergence.

Therefore, fast convergence, low steady-state oscillations and accurate GMPP finding were the most challenges for the previous studies. Our research contribution is to enhance the performance of PSO algorithm in searching GMPP by changing the fitness value according to environmental and load conditions. This proposed system has achieved high resulted output power than the convolutional PSO as well as satisfying the previous challenges.

The objective of this research is to suggest a MPPT methodology based on an improved PSO algorithm. The MPPT algorithm is suitable for centralized Photovoltaic generation system under PSC and normal conditions. The methodology and simulation results have been accomplished by using MATLAB/SIMULINK.

The paper is organized as follows: The output characteristics of the PV arrays and mathematical model of the PV module are introduced in section II. In section III, the mathematical model and the characteristics of the DC-DC converter is presented. Maximum Power Point Tracking is discussed in section IV. Section V introduced the effect of partial condition of shading on Photovoltaic Generation System (PGS). Section VI provides our algorithm in detail. In section VII, the results of the simulations and the practical application are discussed. Finally, the conclusion of the work is presented in section IX. 
TABLE 1

COMPARISON OF DIFFERENT GMPPT APPROACHES FROM PREVIOUS WORK.

\begin{tabular}{|c|c|c|c|c|c|}
\hline Reference & Year & MPPT technique & Controller & $\begin{array}{l}\text { DC-DC } \\
\text { converter }\end{array}$ & Contribution \\
\hline [17] & 2015 & $\begin{array}{l}\text { Hybrid of Ant Colony } \\
(\mathrm{ACO}) \text { and Perturbation } \\
\text { and Observation (P\&O) }\end{array}$ & $\begin{array}{c}\text { DSP and } \\
\text { simulation results }\end{array}$ & Boost converter & Increasing the accuracy of $\mathrm{P} \& \mathrm{O}$ using $\mathrm{ACO}$ \\
\hline [18] & 2016 & $\begin{array}{c}\text { Mine Blast Optimization } \\
\text { (MBO) }\end{array}$ & Simulation results & Boost converter & Evaluating the performance of $\mathrm{MBO}$ algorithm \\
\hline [19] & 2016 & $\begin{array}{c}\text { Teaching - Learning } \\
\text { Based Optimization } \\
\text { (TLBO) } \\
\end{array}$ & Simulation results & Boost converter & Evaluating the performance of TLBO algorithm \\
\hline [20] & 2017 & $\begin{array}{l}\text { Whale Optimization } \\
\text { (WO) with Differential } \\
\text { Evolution (DE) }\end{array}$ & $\begin{array}{c}\text { DSP and } \\
\text { simulation results }\end{array}$ & Boost converter & $\begin{array}{c}\text { A proposed hybrid algorithm based on WO and } \\
\text { DE algorithms }\end{array}$ \\
\hline [21] & 2017 & Jaya and DE & $\begin{array}{c}\text { DSP and } \\
\text { simulation results }\end{array}$ & Boost converter & $\begin{array}{l}\text { A proposed hybrid algorithm based on Jaya and } \\
\text { DE algorithms }\end{array}$ \\
\hline [22] & 2017 & $\begin{array}{l}\text { Shuffled Frog Leap } \\
\text { Algorithm (SFLA) }\end{array}$ & simulation results & Boost converter & Measuring the performance of SFLA technique \\
\hline [23] & 2017 & $\begin{array}{l}\text { Hybrid Shuffled Frog } \\
\text { Leap Algorithm (SFLA) } \\
\text { - PSO algorithm }\end{array}$ & $\begin{array}{c}\text { DSP and } \\
\text { simulation results }\end{array}$ & Boost converter & $\begin{array}{l}\text { Increasing speed of MPPT via PSO } \\
\text { improvement using hybridization with SFLA }\end{array}$ \\
\hline
\end{tabular}

\section{The MaXimum Power Point Tracking System}

The objective of the MPPT system is to increase PV cells efficiency by operating their PV panels at the optimum power point. This system can be shown in Fig.1.

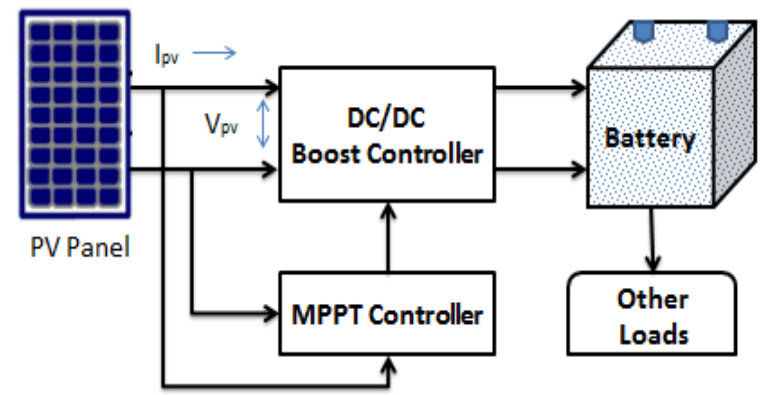

Fig.1: The MPPT System Block Diagram

Figure 1 shows the block diagram of the MPPT system. It consists of PV panel which is the main power source of the system, The MPPT controller which executes a predefined algorithm to find the MPP. The controller inputs are the measured signals of current and voltage of the solar panel. The algorithm performs its calculations according to those signals. The controller produces a modified duty cycle of the Pulse Width Modulation (PWM) technique. It drives a DC-DC inverter switching device. The controller produces a different duty cycle for every different operating point. These sub-modules can be described briefly as follow.

\section{A. Photovoltaic Cell Model}

The solar cell contains mainly of PV wafers [24]. It converts the energy of solar radiation light into voltage, current for load directly, and conducts electricity without electrical influence. The electrical power is obtained directly from the PN interface of the semiconductor; hence the solar cell is also known as the photovoltaic (PV) cell [25]. Several PV cell mathematical models had been used in various studies. Three-diode model [26, 27], Two-diode model [28, 29], and one-diode model [29]. Due to its simplicity, acceptable accuracy and less mathematical manipulation, the one-diode model is the widely used model than other models. Fig. 2 shows the PV cell's equivalent circuit.

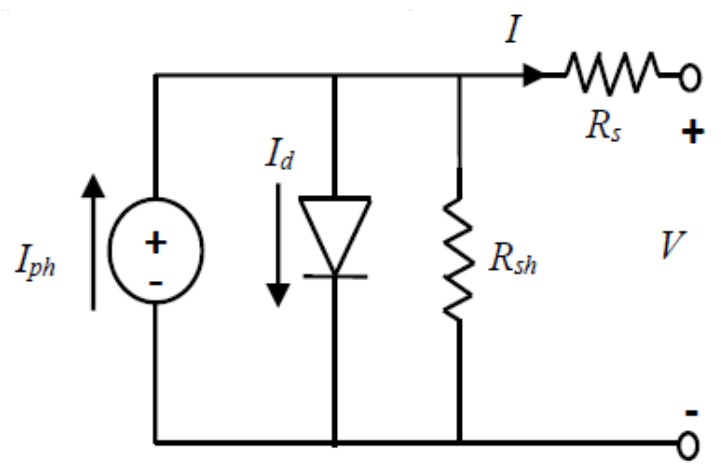

Fig. 2. The PV cell's equivalent circuit

According to Kirchhoff's current law, the output current of the PV cell can be described as:

$$
I=I_{p h}-I_{o}\left(\exp \left[\frac{q\left(V+I R_{S}\right)}{A k T}\right]-1\right)-\frac{V+I R_{S}}{R_{S h}}
$$

Where:

$\mathrm{I}_{\mathrm{ph}}$ : the current produced by the occurrence of light V: the PV cell output voltage

$\mathrm{R}_{\mathrm{s}}, \mathrm{R}_{\mathrm{sh}}$ : the equivalent serial and paroled resistances

$\mathrm{I}_{\mathrm{o}}$ : the reverse saturation current of the diode $\mathrm{q}$ : the charge of the electron $\left(1.6^{*} 10^{-19} \mathrm{C}\right)$

A: the diode ideality constants 
$\mathrm{k}$ : the Boltzmann constant $(1.38 * 10-23 \mathrm{~J} / \mathrm{K})$

$\mathrm{T}$ : the absolute Kelvin temperature

The amount of energy from a single solar cell emitted is very low (200-240 watts). For high-energy generation, the solar cells are connected either in parallel or in series [30] to create PV arrays and PV panels. Table 2 shows the specification of the single PV module 1Soltech 1STH-215P 213.15w that used in the proposed model.

TABLE 2

SPECIFICATIONS OF 1STH-215-P 213.15W PV MODULE

\begin{tabular}{l||c} 
Current at $\mathbf{P}_{\max }\left(\mathbf{I}_{\mathrm{mp}}\right)$ & $7.35 \mathrm{~A}$ \\
\hline Voltage at $\mathbf{P}_{\max }\left(\mathbf{V}_{\mathrm{mp}}\right)$ & $29 \mathrm{~V}$ \\
\hline Maximum power $\left(\mathbf{P}_{\max }\right)$ & $213.15 \mathrm{~W}$ \\
\hline Open-circuit voltage $\left(\mathbf{V}_{\mathbf{o c}}\right)$ & $36.3 \mathrm{~V}$ \\
\hline Short-circuit current $\left(\mathbf{I}_{\text {sc }}\right)$ & $7.84 \mathrm{~A}$ \\
\hline Coefficient of temperature of $\mathbf{V}_{\text {oc }}(\% /$ deg.C) & -0.36099 \\
\hline Coefficient of temperature of $\mathbf{I}_{\mathbf{s c}}(\boldsymbol{\%} / \mathbf{d e g} . \mathbf{C})$ & 0.102
\end{tabular}

The electrical characteristics of PV arrays are dependent on the conditions of the environment. By using PV MATLAB/Simulink model for one parallel panel and three series panels as shown in Fig.3. The mathematical model for the PV arrays in general form can be written as [31]:

$I=N_{P} I_{p h}-N_{P} I_{o}\left(\exp \left[\frac{q\left(V / N_{S}+I R_{S} / N_{p}\right)}{A k T}\right]-1\right)-\frac{V\left(\frac{N_{P}}{N_{S}}\right)+I R_{S}}{R_{S h}}$

Where $\mathrm{N}_{\mathrm{p}}$ is the number of PV modules that connected in parallel and $\mathrm{N}_{\mathrm{s}}$ is the number of $\mathrm{PV}$ modules that connected in series.

With different irradiance conditions, Fig. 4(a) shows the $\mathrm{P}-\mathrm{V}$ and I-V characteristics of the PV array model and Fig. 4(b) shows the P-V and I-V characteristics of the PV array model at different temperatures and under variable environmental conditions. The values of the temperature were adjusted between $10^{\circ} \mathrm{C}$ and $70^{\circ} \mathrm{C}$ while the curves of the characteristics of the obtained PV array and the irradiance values were modified between $100 \mathrm{~W} / \mathrm{m}^{2}$ and $1000 \mathrm{~W} / \mathrm{m}^{2}$ keeping the temperature value constant at $25^{\circ} \mathrm{C}$.

The characteristics of a PV cell depend directly on temperature and irradiance. Fig. 4(a) shows that, the output current $\mathrm{I}_{\mathrm{pv}}$ is significantly affected by the radiation change. While the voltage of the output $\mathrm{V}_{\mathrm{pv}}$ remains almost constant and clearly shows that maximum power is present on the power curves which leads to the MPP.

As shown in Fig. 4(b), when temperature was increased, both of the open circuit voltage and the maximum power have been decreased.

Temperature is a very critical behavioral parameter of those solar cells. The temperature also affects the PV cell characteristics. Fig. 4(b) shows the variation of the PV cell characteristics as a temperature function at a given radiation. When temperature has been changed, the current remains constant while the voltage values change, considerably.

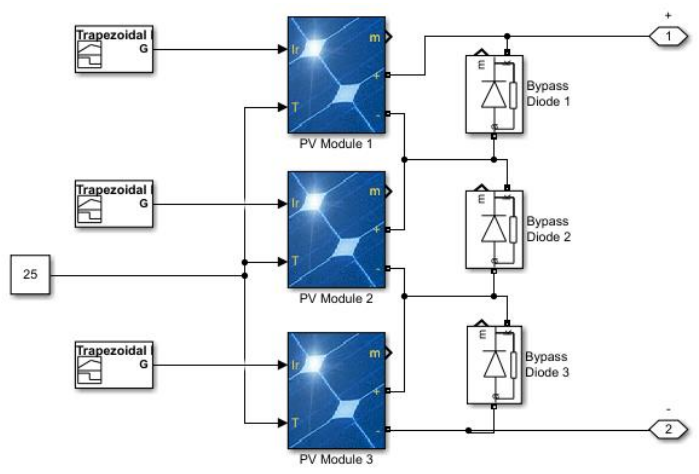

Fig.3: PV array Model
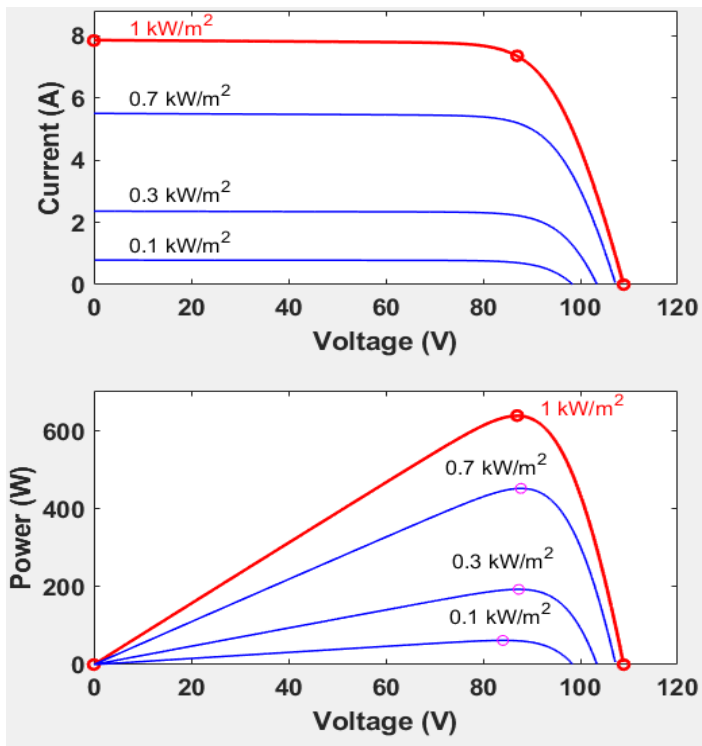

(a)
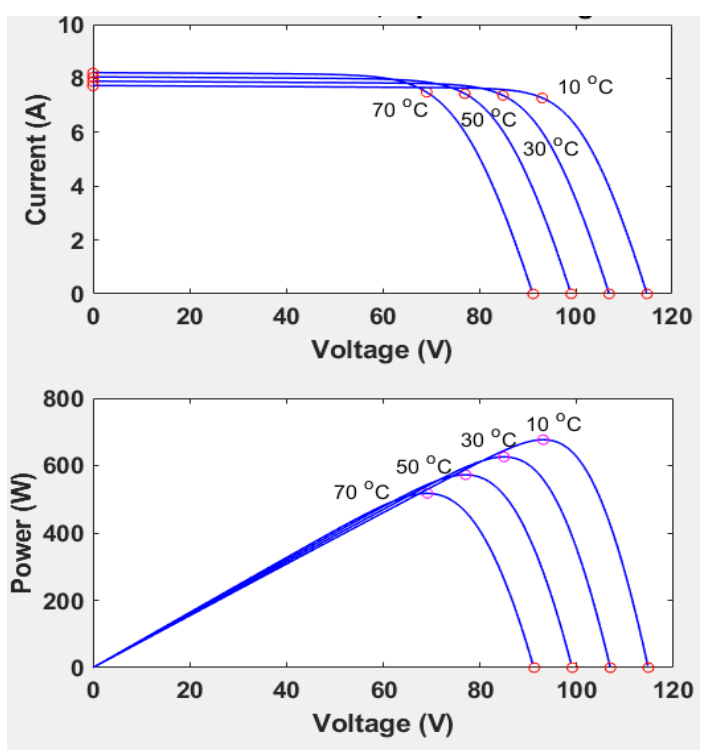

(b)

Fig.4: (a) I-V and P-V characteristic of PV array (Variable radiation, $\mathrm{W} / \mathrm{m} 2$ ),

(b) I-V and P-V characteristic of PV array (variable temperature, $\left.{ }^{\circ} \mathrm{C}\right)$. 


\section{B. DC-DC Boost Converter}

The boost converter is essential to the photovoltaic generation process because the boost converter tracks the MPP created by the PV panel that allows the adjustment of the voltage provided by the panel by acting on its duty cycle d [32].

The step-up converter (boost converter) has been connected between the PV array and the load. It includes boost inductor, MOSFET used as a switch, diode, resistive load and capacitance of the output filter. An output capacitor is connected to the load to maintain a constant voltage. The feedback provided by the control unit connected to the output of the boost converter. Fig. 5(a) and 5(b) show the boost converter's equivalent circuit when the switch is opened and closed, respectively [33].

As shown in Fig. 5(a), dynamic system equations in open switch operation can be represented by Eqs. (3) and (4).

$$
\begin{aligned}
& \dot{v}_{p v}=-\frac{1}{c_{1}} i_{L}+\frac{1}{c_{1} r_{p v}} v_{p v} \\
& \dot{i}_{L}=\frac{1}{L} v_{p v}-\frac{1}{L} v_{o}
\end{aligned}
$$

As shown in Fig. 5(b), at closed switch, then

$\dot{v}_{p v}=-\frac{1}{c_{1}} i_{L}+\frac{1}{c_{1} r_{p v}} v_{p v}$

$i_{L}=\frac{1}{L} v_{p v}$

In the previous equations, $r_{p v}$ is the dynamic resistance of the solar panel and $v_{o}$ is the voltage of the load, which is defined by Eq. (7).

$r_{p v}=-\left(\frac{\partial v_{p v}}{\partial i_{p v}}\right)$

Eqs. (3)-(6), both in closed and open switch operations, differ in only one part. Assuming $d$ is the duty cycle, and $u$ is the control signal to control the switch, it is possible to rewrite these equations into Eq. (8) and Eq. (9) in the form of state space.

$\dot{v}_{p v}=-\frac{1}{c_{1}} i_{L}+\frac{1}{c_{1} r_{p v}} v_{p v}$

$\dot{i}_{L}=\frac{1}{L} v_{p v}-(1-d) \frac{1}{L} v_{o}$

In these equations, $\mathrm{d}=1$ and $\mathrm{d}=0$ indicates closed and open switch operations, respectively. In above equations, $\mathrm{d}$ is the system input variable, $\mathrm{i}_{\mathrm{L}}$ and $\mathrm{v}_{\mathrm{pv}}$ are state variables.
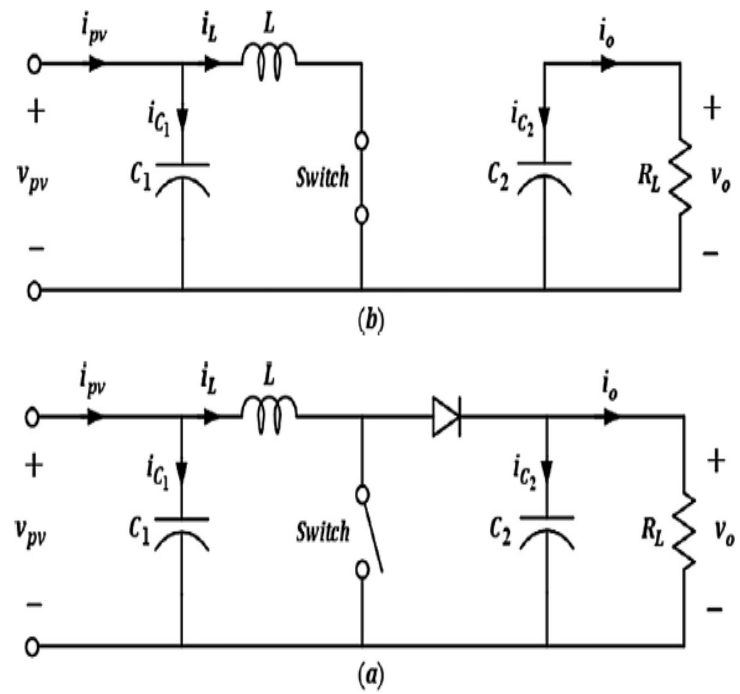

Fig. 5. Equivalent circuit of boost converter, (a) open switch, (b) closed switch.

\section{Maximum Power Point Tracking}

As solar panels are operated at the voltage where the global maximum for the P-V characteristic is located, maximum power (MP) is acquired. So, the maximum output power of the solar panel can be obtained for one particular operating point. This point located in the curve of the P-V characteristic known as Maximum Power Point (MPP). This point often lies on the knee of the solar panels' I-V curve. Briefly, it can be inferred that there is a point on the I-V curve of the solar panel called Maximum Power Point (MPP) that always occurs on the knee of the curve where the generated PV power is maximized. Figure 6 shows that, the MPP that found on the knee of the I-V curve specified by a red dot. MPP position is continually being changed, when the irradiation and temperature values have been changed. The radiation and temperature have dynamical nature, so the MPP tracking algorithm can work basically in real time by constantly updating the duty cycle thus maintaining tracking speed and accuracy [34].

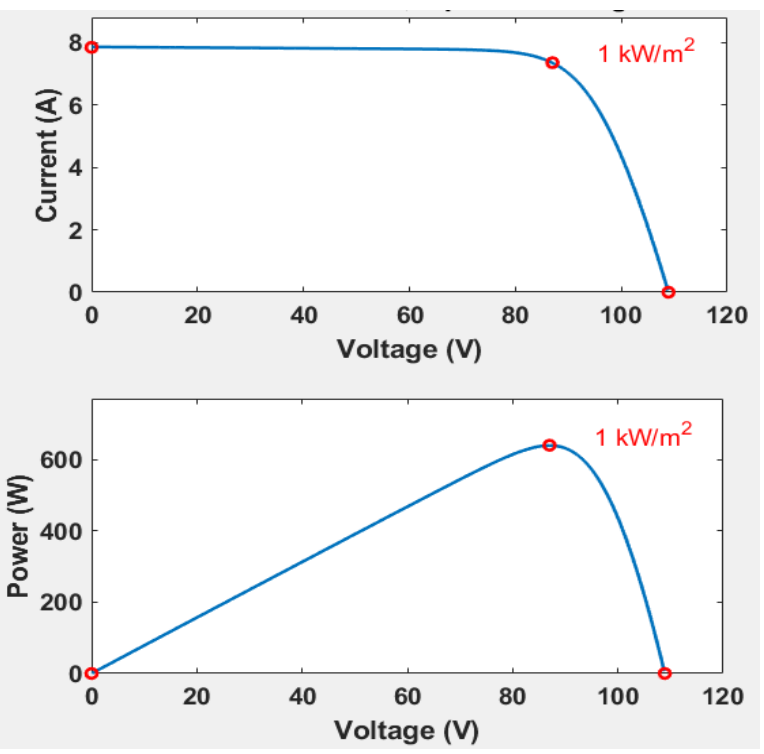

Fig.6. I-V \& P-V characteristic curves 
The controller is used to track permanently variable MPPs; it is called Maximum Power Point Tracker (MPPT). This controller consists of two major parts, a tracking algorithm for tracking the MPP, and DC-DC boost converter to convert the induced voltage to the required load level. The tracking algorithm to satisfy MPP can be implemented using microcontroller. The MPP is tracked using many different algorithms [35]. However, most of these algorithms do not work properly in the case of rapid differences such as 1) rapid change in radiance levels and 2) the partial shading of the solar panel [36]. But, providing a technique that can provide precise control signals even during rapid change of radiance levels or the partial shading of the solar panels is very important for the device. Hence, the algorithm's effectiveness is very important.

\section{D.Effect of partial condition of shading on Photovoltaic Generation System (PGS)}

The Photovoltaic module consists of many PV cells that are connected in series to generate a higher voltage and parallel to increase the current of the output. Afterwards, multiple PV modules are connected in parallel/series to form a Photovoltaic Generation System (PGS). Due to the bypass diodes, the $\mathrm{P}-\mathrm{V}$ curve of the $\mathrm{PV}$ module can displays several MPPs under Partial Shading Conditions (PSC). Under PSC, the PV module's characteristics with connected bypass diodes at the end of the module can be described as follows:

- Under PSC, the shaded cells serve as a load rather than a generator and create a hotspot.

- To avoid this problem, bypass diodes of these shaded cells will thus be created.

- Because the shaded cells are exceeded, several peaks in the $\mathrm{P}-\mathrm{V}$ curve will be shown.

- Depending on the shading pattern type, GMPP may occur in the higher or lower voltage range.

This phenomenon makes it difficult for applying specifically the conventional techniques of MPPT. But, bio-inspired techniques can track MPPT under PSC effectively.

\section{OVERVIEW OF The CONVENTIONAL PSO ALgorithm}

A simple bio-inspired technique used for nonlinear optimization problems is Particle Swarm Optimization (PSO). It is inspired from bird flocking, fish schooling or the interaction of bees in search of food. The PSO algorithm is developed and widely used for optimization and application design in different fields of science and engineering. Generally speaking, PSO operates on two main principles; one is to learn from past data and the other is to communicate current information between the swarm agents [37].
PSO technology contains a number of particles. A number of particles are found in PSO technology. By replacing the data obtained in their research process, each particle proposes a solution to find the best solution. Based on a simple mathematical relationship, these particles move around the search field. [38].

The position and velocity of the particles are updated according to Eqs. (10) and (11). In this research, the particle swarm position is taken as the duty cycle and the fitness function is the output power of the PV system. By the following equations, the particle position $\mathrm{d}_{\mathrm{i}}$ is updated [39]; $d_{i}^{k+1}=d_{i}^{k}+v_{i}^{k+1}$

Where:

$\mathrm{v}_{\mathrm{i}}$ is the step size at the iteration $\mathrm{k}+1$

$v_{i}^{k+1}=w v_{i}^{k}+c_{1} r_{1}\left(P_{\text {best }}-d_{i}^{k}\right)+c_{2} r_{2}\left(G_{\text {best }}-d_{i}^{k}\right)$

Where:

$r_{1}$ and $r_{2}$ are random values from $[0,1]$;

$\mathrm{w}$ is the inertial weight;

$c_{1}$ and $c_{2}$ is the acceleration coefficients;

$\mathrm{G}_{\text {best }}$ is the best position in whole population

$\mathrm{P}_{\text {best }}$ is the best position of particle $\mathrm{i}$;

The main objective of the PSO is to track MPP and adjust the duty cycle of the DC-DC converter to obtain the maximum allowable power to the load. The PV system by nature has a maximum power point. But, in case of shading, the system has multiple power points, and the desired procedure is to find GMPP. If the solar insolation is changed, there is a new GMPP. The PSO algorithm initiates particles as iterations, duty cycle ranges and the weights. According to the initial particle, the algorithm calculates the required duty cycle for driving the DC converter with measuring the resulted PV voltage, current and power. If the resulted power (fitness) is better as individual particle, then update the duty cycle as the best position. This procedure will be repeated for all particles until reaching the GMPP. In the conventional PSO the particles not reinitialized even if the pattern shading changed, that means the duty cycle still fixed so it cannot obtain the new GMPP. But, in the proposed methodology, the particles are reinitialized, that means the duty cycle will be changed. So, a new GMPP can be obtained. Therefore, the enhanced PSO algorithm can achieve high resulted output power than the conventional PSO; this will be illustrated in the simulation results. 


\section{PROPOSED METHOD}

In this section, the flowchart of the improved PSO algorithm is shown in Fig.7. It shows that the operating principles of the technique can be described as follows:

\section{Step 1: (PSO parameter initialization):}

PSO parameters were initialized and number of duty cycles was randomly assigned.

\section{Step 2: (Fitness evaluation):}

Each parameter is applied to Photovoltaic Power System (PVPS). PVPS (Photovoltaic Power System) is applied to each parameter. To estimate PVPS power, the system's voltage and current are measured. The fitness function of particle $\mathrm{i}$ is this power. Determine the value of $\mathrm{P}_{\text {best }}$.

Step 3: (Update the best individual and global data):

A comparison is made between the corresponding $\mathrm{P}_{\text {best }}$ stored energy in the register and the new fitness value. The new rated power is chosen as the best fitness value, if it is greater than the previous one.

\section{Step 4: (Position and velocity update of each particle):}

It is possible to update the old position and velocity for all particles after evaluating all of them based on Eq. (10) and Eq. (11).

\section{Step 5: (Convergence determination):}

The PSO-based tracker stops when the stopping criterion is reached and gives the best duty cycle that corresponds to global power. If there is any change in the shading pattern, that causes the revert to step 2 to tracking the new MPP.

\section{Step 6: (Reinitialization):}

Usually the PSO method is used to solve problems for which the optimum solution is fixed time. However, in this application, the fitness value (the GMPP) often changes with the environmental conditions as well as loading conditions. In such cases, to search for the new GMPP again, the particles must be reinitialized. The following constraint is used in this paper to detect changes in insolation and shading patterns. Whenever the following condition that shown in Eq. (12) is met, the proposed PSO algorithm reinitializes the particles.

$$
\frac{\left|P_{p v, n e w}-P_{p v, l a s t}\right|}{P_{p v, l a s t}} \geq \Delta P(\%)
$$

So, the difference between the conventional method and the improved method is that if there is any change in the shading pattern in the improved method, the steps of the operating principle of the algorithm return to start from the second step. Also the duty cycle changes if the shading pattern is changed but in the conventional method, the duty cycle only change at the beginning of the system work then it is fixed even if the shading pattern changed and the steps not repeated.

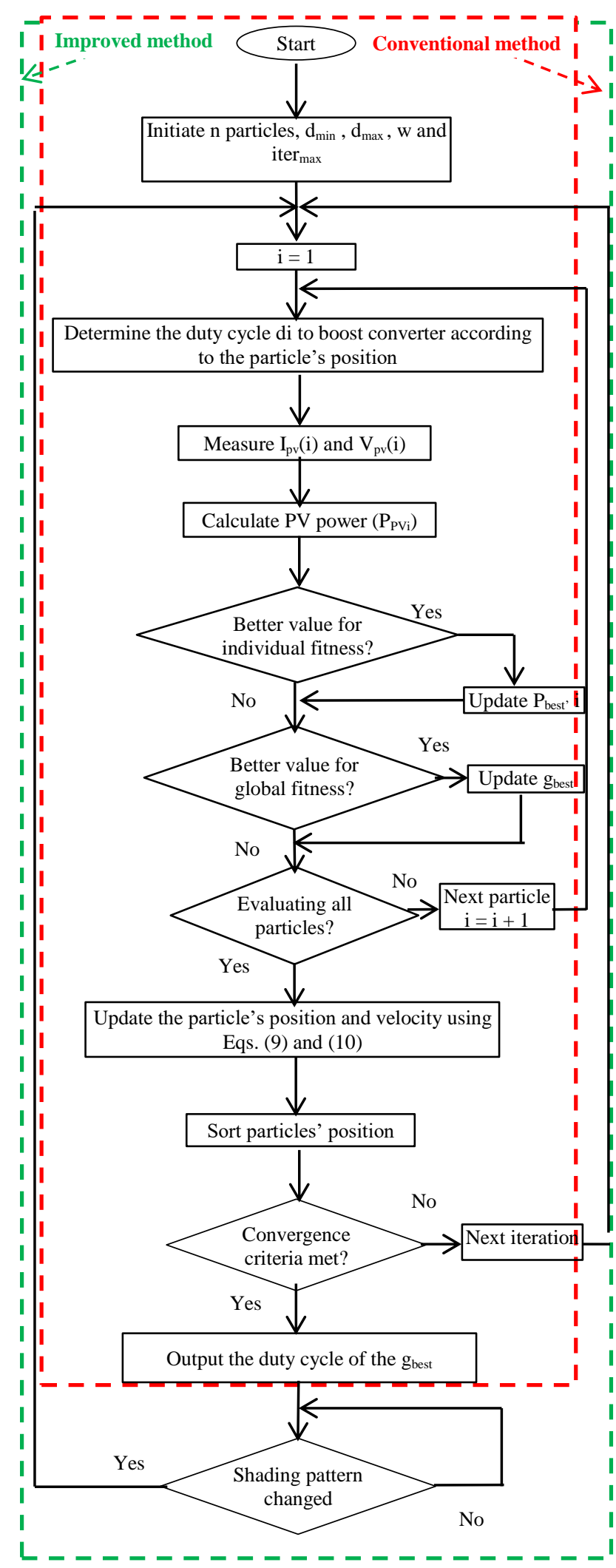

Fig.7. The flowchart of the searching mechanism of the improved PSO.

\section{Simulation AND DiscuSSION}

In the MATLAB/SIMULINK software, a PV system including: one solar panel, a DC-DC boost converter, and controller (improved PSO MPP tracker) are considered and 
simulated to verify the performance and accuracy of the proposed method. The studied solar panel contains 1 parallel string and 3 series cells per string. Fig. 8 displays the system simulated by MATLAB, while the PV array components are shown in Fig.2 (as stated before).

According to the design guideline described in Section IV, Table 3 shows the suggested parameter settings for the MPPT-based PSO technology. In the simulation procedure, the cell temperature is assumed to be constant at $25{ }^{\circ} \mathrm{C}$. At $1000 \mathrm{~W} / \mathrm{m}^{2}$, un-shaded cells are considered fully lit. Insolation on shaded cells ranges from 0 to $1000 \mathrm{~W} / \mathrm{m}^{2}$.

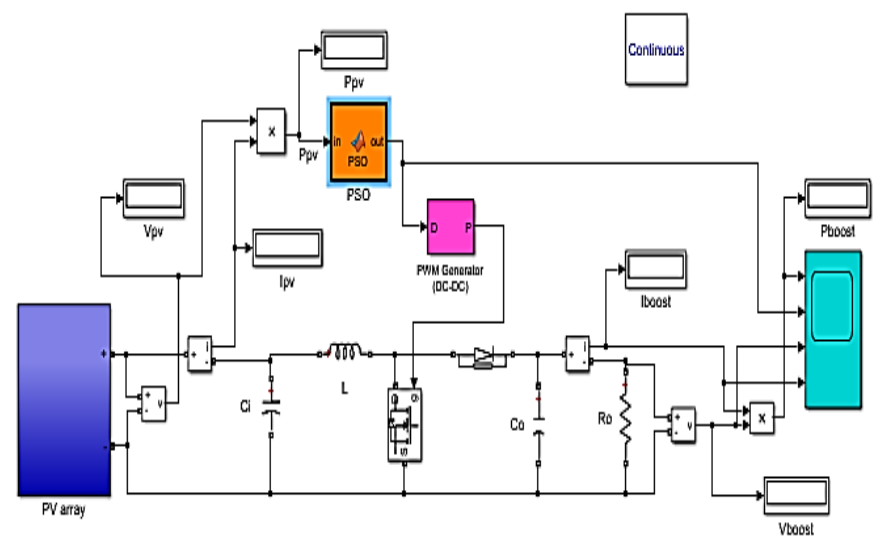

Fig. 8. The system configuration

TABLE 3

PARAMETER SETTINGS OF THE IMPLEMENTED ALGORITHM

\begin{tabular}{|c||c||c||c|} 
Number of particles & 3 & W & 0.3 \\
\hline Maximum iterations & 10 & $\mathbf{c}_{\mathbf{1}}$ & 0.6 \\
\hline Var $_{\text {min }}$ & 0.1 & $\mathbf{c}_{\mathbf{2}}$ & 0.7 \\
\hline $\mathbf{V a r}_{\text {max }}$ & 0.92 & $\mathbf{r}_{\mathbf{1}}$ & 0.25 \\
\hline & & $\mathbf{r}_{\mathbf{2}}$ & 0.25 \\
\hline
\end{tabular}

As a case study, the effect of using the improved PSO algorithm is introduced in non-shading and partial shading cases. The radiation on the PV cells at the non-shading condition shown in Fig.9. While, Fig.10 shows the response of power, duty cycle, volt and current respectively.

\section{A. Case 1: At the non-shading condition}

At the non-shading condition, there is no difference in the results between the conventional PSO and improved PSO, because the system has only one fixed GMPP. From Fig.10(a), it was observed that the PSO has tracked the system after 0.18 s to reach the GMPP (i.e $638.9 \mathrm{~W}$ ) and the efficiency of the tracking is $99.98 \%$. Figure 10(b) shows that the value of the duty cycle has stabilized at $52 \%$ without oscillations. Figure 10(c) and Fig.10(d) show the volt and the current response curves that are generated by the boost converter. From Fig.10(a),(b),(c) and (d), it is noted that, there are few ripples at the beginning of the tracking procedure but the system stabilizes after $0.18 \mathrm{~s}$.

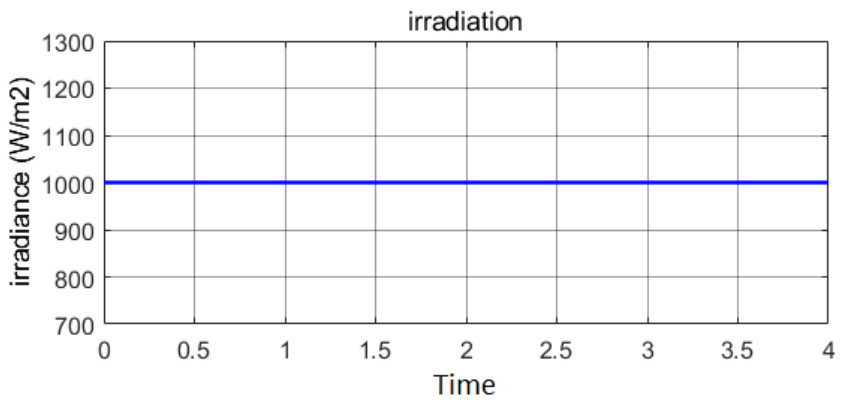

Fig.9. The radiation at non-shading condition

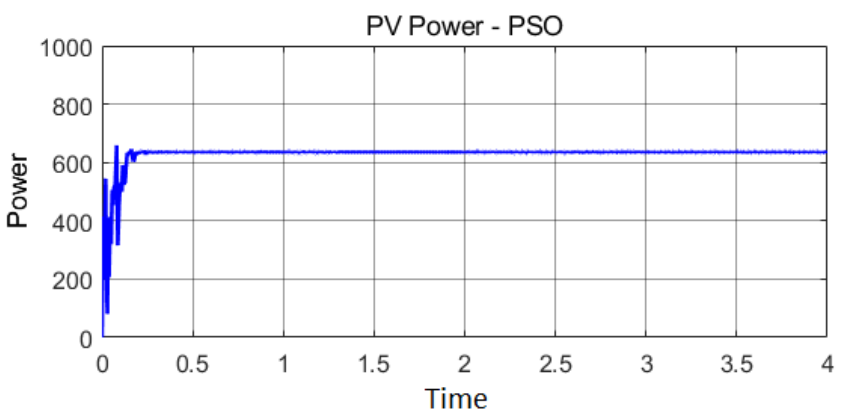

(a)

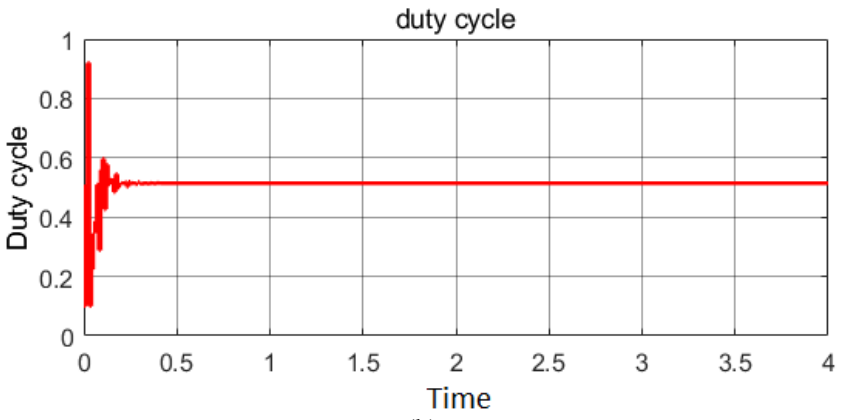

(b)

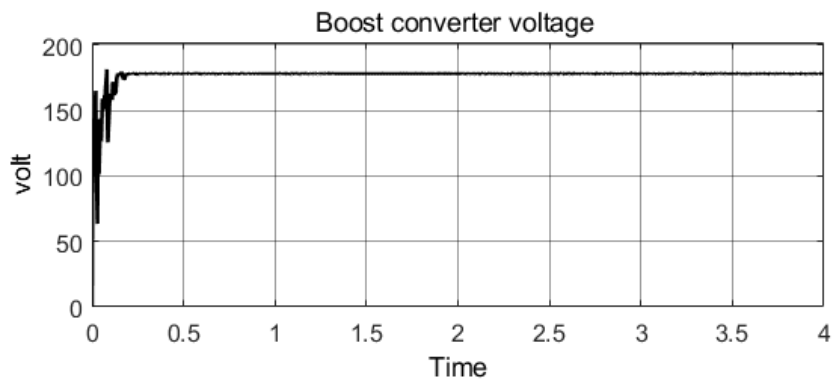

(c)

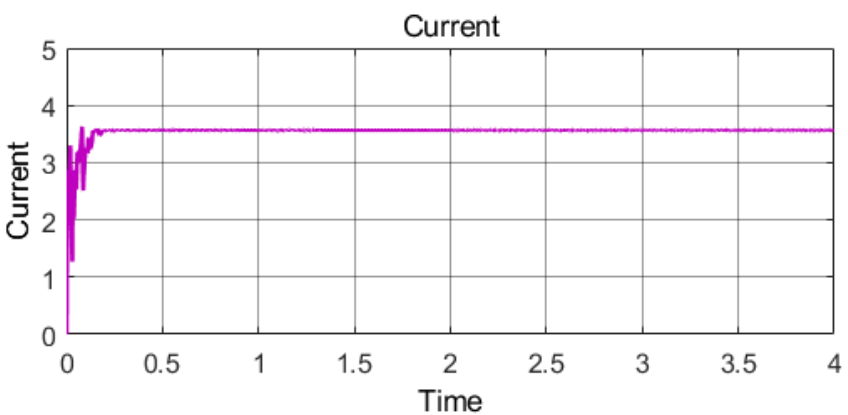

(d)

Fig.10. Results of simulation under irradiance $=1000 \mathrm{~W} / \mathrm{m} 2, \mathrm{Tc}=25^{\circ} \mathrm{C}$ : (a) Power, (b) Duty cycle, (c) Voltage, (d) Current. 


\section{B. Case2: at the partial condition of shading}

At the partial shading condition, the irradiance varies from $500 \mathrm{~W} / \mathrm{m}^{2}$ to $1000 \mathrm{~W} / \mathrm{m}^{2}$. Figure 11 shows the irradiance on the PV cells at the shading condition.

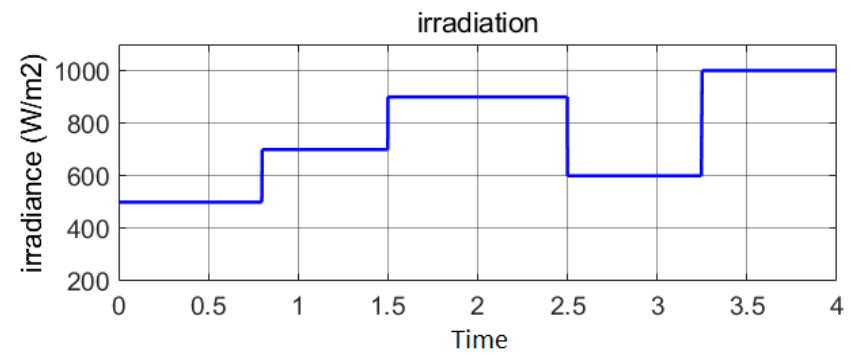

Fig.11 the irradiation at the shading condition

Figure 11 shows the irradiation at the partial shading condition that varies from $500 \mathrm{~W} / \mathrm{m}^{2}$ to $1000 \mathrm{~W} / \mathrm{m}^{2}$. According to Fig.10, there is a discrepancy in results between the conventional and the modified PSO algorithms. Figure 12 and Fig.13 show the responses of power, duty cycle, voltage and current in the conventional PSO method and improved PSO method respectively.

\section{1) Conventional PSO method}

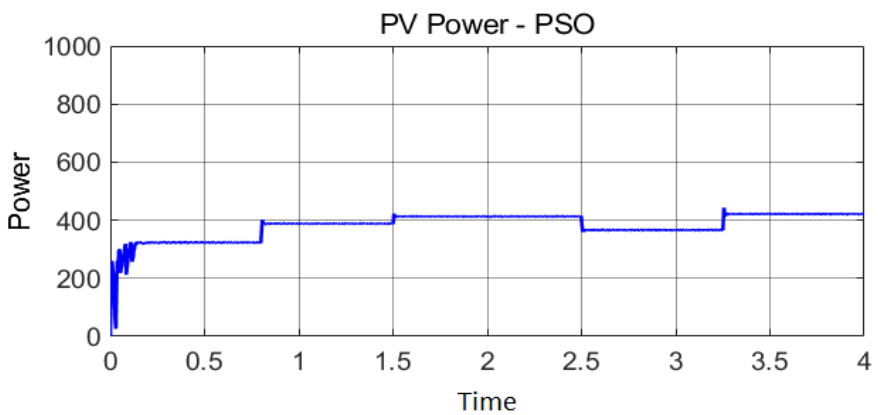

(a)

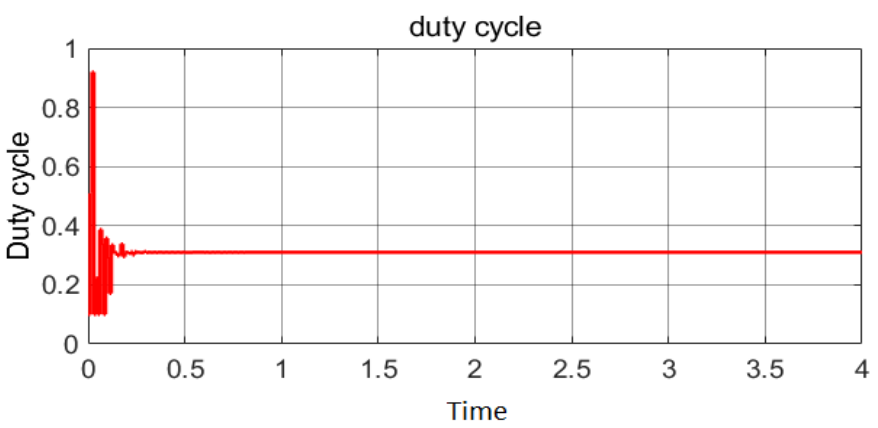

(b)

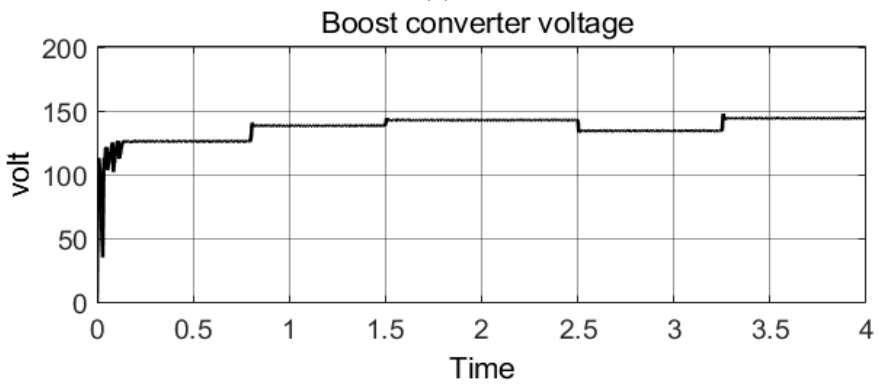

(c)

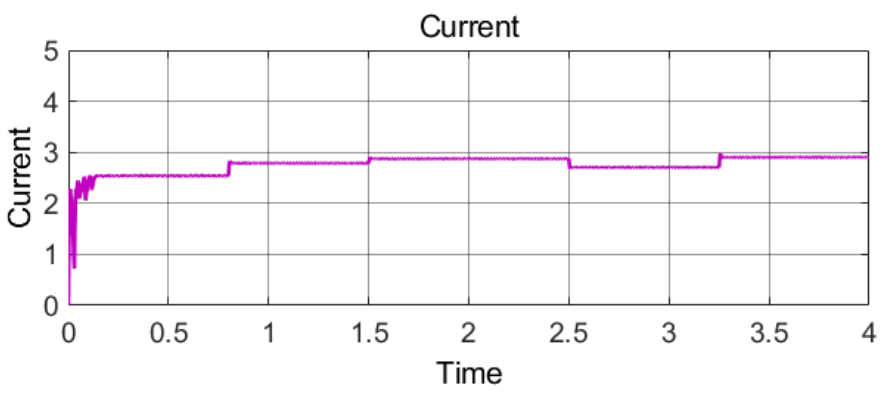

(d)

Fig.12. Results of simulation under partial shading (conventional PSO method): (a) Power, (b) Duty cycle, (c) Voltage, (d) Current

\section{2) Improved PSO method}

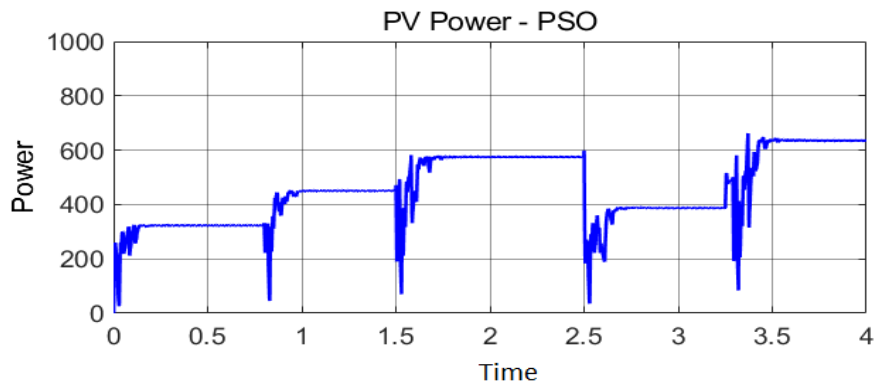

(a)

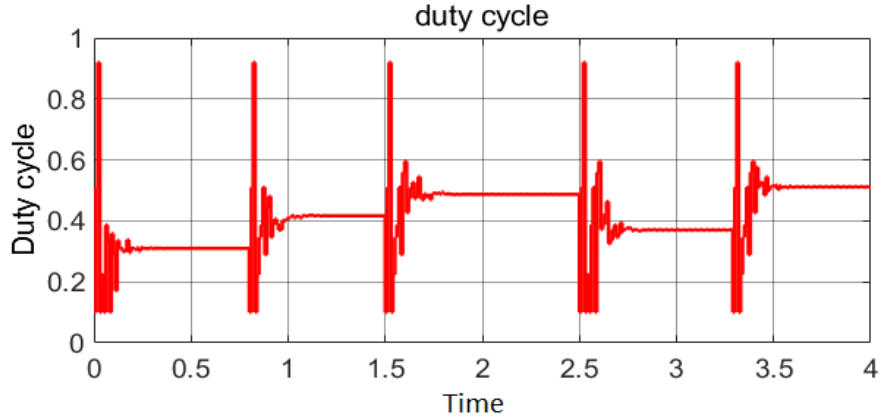

(b)

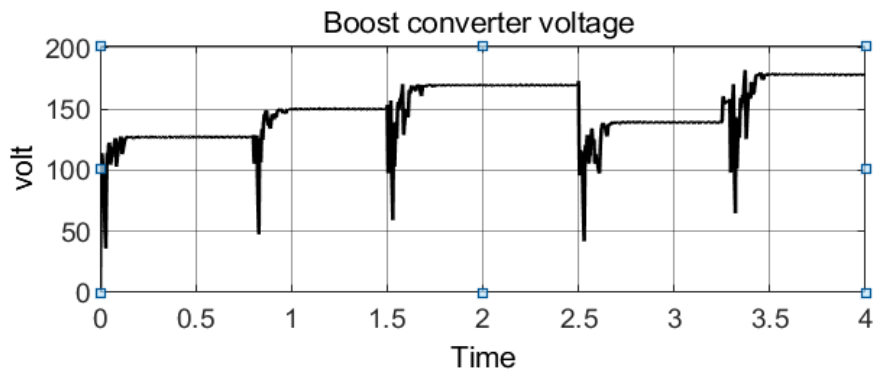

(c)

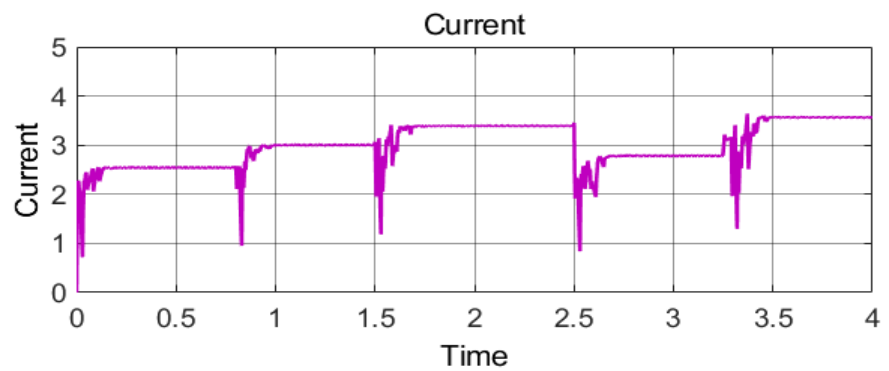

(d)

Fig.13. Results of simulation under partial shading (improved PSO method): (a) Power, (b) Duty cycle, (c) Voltage, (d) Current 
Form Fig.12, it is noted that, due to the conventional PSO algorithm did not reinitialize the particles after the new shading conditions, the system has a constant duty cycle for all shading conditions. While in Fig.13, the modified PSO algorithm has several duty cycles during the system operation related to the new resulted GMMP, this is due to the multi-shading patterns as in Fig.11. Table 4 and Table 5 conclude the result of the conventional and improved PSO algorithms.

TABLE 4

RESULTS OF THE CONVENTIONAL PSO

\begin{tabular}{|c|c|c|c|c|c|c|}
\hline $\begin{array}{c}\text { Irradiance } \\
\left(\mathbf{W} / \mathbf{m}^{2}\right)\end{array}$ & $\begin{array}{l}\text { MAX. } \\
\text { Peak }\end{array}$ & $\begin{array}{c}\text { Time } \\
\text { required } \\
\text { to reach } \\
\text { to steady } \\
\text { state }(s)\end{array}$ & $\begin{array}{c}\text { MAX. } \\
\text { voltage } \\
\text { (Volt) }\end{array}$ & $\begin{array}{l}\text { MAX. } \\
\text { current } \\
\text { (A) }\end{array}$ & $\begin{array}{l}\text { MAX. } \\
\text { power } \\
\text { (Watt) }\end{array}$ & Ripples \\
\hline 500 & 324.5 & 0.21 & 127.3 & 2.55 & 324.2 & Low \\
\hline 600 & 413.9 & 0.53 & 135.1 & 2.71 & 365.6 & No \\
\hline 700 & 400.4 & 0.84 & 139.5 & 2.8 & 386.6 & No \\
\hline 900 & 422.2 & 1.55 & 143.9 & 2.86 & 411.6 & No \\
\hline 1000 & 442.5 & 3.29 & 144.9 & 2.9 & 420 & No \\
\hline
\end{tabular}

TABLE 5

RESULTS OF THE IMPROVED PSO

\begin{tabular}{|c|c|c|c|c|c|c|}
\hline $\begin{array}{c}\text { Irradiance } \\
\left(\mathbf{W} / \mathbf{m}^{2}\right)\end{array}$ & $\begin{array}{c}\text { MAX. } \\
\text { Peak }\end{array}$ & $\begin{array}{c}\text { Time } \\
\text { required } \\
\text { to reach } \\
\text { to steady } \\
\text { state }(\mathrm{s})\end{array}$ & $\begin{array}{l}\text { MAX. } \\
\text { voltage } \\
\text { (Volt) }\end{array}$ & $\begin{array}{l}\text { MAX. } \\
\text { current } \\
\text { (A) }\end{array}$ & $\begin{array}{l}\text { MAX. } \\
\text { power } \\
\text { (Watt) }\end{array}$ & Ripples \\
\hline 500 & 325 & 0.21 & 127.3 & 2.55 & 324.2 & Low \\
\hline 600 & 598.2 & 0.73 & 139.5 & 2.8 & 389.2 & Low \\
\hline 700 & 452.5 & 1.0 & 150.1 & 3.02 & 452.5 & Low \\
\hline 900 & 580.2 & 1.76 & 169.9 & 3.39 & 576.1 & Low \\
\hline 1000 & 661.1 & 3.6 & 178.7 & 3.58 & 639.9 & Low \\
\hline
\end{tabular}

As shown in Table 4 and Table 5, the improved PSO algorithm has achieved high output power than the conventional PSO regarding to the different shading patterns. The proposed system is slightly slower and has slight ripples than the conventional one; this is due to the particles re-initialization. The average rate of increase in the output power in case of improved PSO is $21 \%$. As well as, the improved method has high max peak, voltage and current. So, the improved technique of the PSO algorithm improves the performance of the conventional PSO algorithm.

To ensure the effectiveness of the proposed system, a comparative study is shown in Table 6. The table lists different meta-heuristics MPPT techniques, that have been presented in other researchers based on tracking GMPP under PSC. The tracking efficiency, the implementation complexity, tracking speed and the implementation cost are the main comparison topics. All techniques had used shading pattern with irradiance varied from $350 \mathrm{~W} / \mathrm{m}^{2}$ to $950 \mathrm{~W} / \mathrm{m}^{2}$.
TABLE 6

COMPARISON BETWEEN THE PROPOSED METHOD AND THE OTHER METHODS.

\begin{tabular}{c||c||c||c||c||c} 
Algorithms & GMPP & Efficiency & $\begin{array}{c}\text { Implementation } \\
\text { complexity }\end{array}$ & $\begin{array}{c}\text { Speed } \\
\text { (s) }\end{array}$ & Cost \\
\hline $\begin{array}{c}\text { Grey-Wolf } \\
\text { optimization } \\
\text { (GWO) [40] }\end{array}$ & Yes & $99.9 \%$ & High & 3.18 & High \\
\hline $\begin{array}{c}\text { Simulated } \\
\text { annealing } \\
\text { (SA) [41] }\end{array}$ & $\begin{array}{c}\text { Around } \\
\text { GMPP }\end{array}$ & $92.17 \%$ & High & 2.9 & High \\
\hline $\begin{array}{c}\text { Artificial } \\
\text { bee colony } \\
\text { (ABC) [42] }\end{array}$ & Yes & $99.8 \%$ & Medium & 2.1 & Medium \\
\hline $\begin{array}{c}\text { Firefly } \\
\text { Algorithm } \\
\text { (FA) [43] }\end{array}$ & Yes & $99.97 \%$ & Medium & 2.03 & Medium \\
\hline $\begin{array}{c}\text { Proposed } \\
\text { method }\end{array}$ & Yes & $99.99 \%$ & Medium & 1.88 & Medium \\
\hline
\end{tabular}

From Table 6, most of the techniques had achieved higher efficiency that reaches $99.9 \%$ except SA [40] had less efficiency with $92.17 \%$. The proposed PSO, (ABC) [41] and (FA) [42] techniques have medium implementation complexity and cost values, while (GWO) [39] and (SA) [41] have higher implementation complexity and cost values. The average tracking time is shown in Table 6, the proposed improved PSO technique had achieved the faster response with 1.88s, then (FA) [42] with $2.03 \mathrm{~s}$ and (ABS) [41] with 2.1s. So, it can be concluded that the proposed method has more benefits than other recent meta-heuristics techniques.

\section{Conclusion}

Solar energy is considered as one of the most cheap, clean and important renewable energy sources. To utilize this energy, photovoltaic systems are used to transform solar energy into electricity. But, the resulted power depends on the ambient conditions, therefore, according to the PV nature, the P-V characteristics may have multiple power points. So, the main objective of this research is to develop an improved GPPT system for optimizing the resulted output power.

The supposed system is based on improving the PSO algorithm for tracking the MPP of PV system under normal and partial shading conditions. The improved technique is based on re-initialize the PSO particles for searching the new GMPP again after the system is supposed to partial shading condition. This leads to use different duty cycles during the tracking system, rather than a constant duty cycle in conventional PSO system. The improved PSO system had achieved increasing in the average output power by $21 \%$. The system model was built by MATLAB/SIMULINK.

To verify the effectiveness of the proposed technique, comparative evaluation was used for comparing the proposed improved PSO algorithm with other metaheuristics techniques. The proposed technique has achieved acceptable speed with $0.18 \mathrm{~s}$, medium cost and medium implementation complexity results. So, the improved PSO 
algorithm has high accuracy and can track the real MPP under various radiation and partial shading conditions.

\section{AUTHORS CONTRIBUTION}

Mohamed S. M. ELKsas and Mohamed M. Abdelsalam conceived of the presented idea. Hend Samir Saad developed the theory and performed the computations. Mohammad M. Abdelsalam and Hend Samir Saad verified the analytical methods. Sabry F. Saraya and Mohammad M. Abdelsalam have suggested Hend Samir Saad to investigate the comparison between shading and non-shading techniques using PSO algorithm and supervised the findings of this work. All authors discussed the results and contributed to the final manuscript. Hend Samir Saad wrote the manuscript with support from Mohamed S. M. Elksas and Mohamed M. Abdelsalam. Sabry F. Saraya and Mohamed M. Abdelsalam responded to the critical review of the article.

\section{REFERENCES}

[1] H. Li, D. Yang, W. Su, J. Lü, and X. Yu, "An overall distribution particle swarm optimization MPPT algorithm for photovoltaic system under partial shading," IEEE Transactions on Industrial Electronics, vol. 66, no. 1, pp. 265-275, 2018.

[2] J. P. Ram, T. S. Babu, and N. Rajasekar, "A comprehensive review on solar PV maximum power point tracking techniques," Renewable and Sustainable Energy Reviews, vol. 67, pp. 826-847, 2017.

[3] B. Bendib, H. Belmili, and F. Krim, "A survey of the most used MPPT methods: Conventional and advanced algorithms applied for photovoltaic systems," Renewable and Sustainable Energy Reviews, vol. 45, pp. 637-648, 2015.

[4] T. Anuradha, P. D. Sundari, S. Padmanaban, P. Siano, and Z. Leonowicz, "Comparative analysis of common MPPT techniques for solar PV system with soft switched, interleaved isolated converter," in 2017 IEEE International Conference on Environment and Electrical Engineering and 2017 IEEE Industrial and Commercial Power Systems Europe (EEEIC/I\&CPS Europe), 2017: IEEE, pp. 16.

[5] J. Ahmed and Z. Salam, "An improved perturb and observe (P\&O) maximum power point tracking (MPPT) algorithm for higher efficiency," Applied Energy, vol. 150, pp. 97-108, 2015.

[6] Y. Cheddadi, F. Cheddadi, F. Errahimi, and N. Es-Sbai, "Extremum seeking control-based global maximum power point tracking algorithm for PV array under partial shading conditions," in 2017 International Conference on Wireless Technologies, Embedded and Intelligent Systems (WITS), 2017: IEEE, pp. 1-6.

[7] S. K. Kollimalla and M. K. Mishra, "A novel adaptive P\&O MPPT algorithm considering sudden changes in the irradiance," IEEE Transactions on Energy conversion, vol. 29, no. 3, pp. 602-610, 2014.

[8] A. R. Reisi, M. H. Moradi, and S. Jamasb, "Classification and comparison of maximum power point tracking techniques for photovoltaic system: A review," Renewable and sustainable energy reviews, vol. 19, pp. 433-443, 2013.

[9] S. Obukhov, A. Ibrahim, and R. Aboelsaud, "Maximum power point tracking of partially shading PV system using particle swarm optimization," in Proceedings of the 4th International Conference on Frontiers of Educational Technologies, 2018, pp. 161-165.

[10] O. T. A. Perturb, "A Comprehensive Review on Various Optimization Techniques Assisted Perturb and Observe MPPT Algorithm for a PV System," International Journal of Pure and Applied Mathematics, vol. 118, no. 5, pp. 51-63, 2018.

[11] N. Priyadarshi, V. K. Ramachandaramurthy, S. Padmanaban, and F. Azam, "An ant colony optimized MPPT for standalone hybrid PVwind power system with single Cuk converter," Energies, vol. 12, no. 1, p. 167, 2019.

[12] S. Hassan, B. Abdelmajid, Z. Mourad, S. Aicha, and B. Abdenaceur, "An advanced MPPT based on artificial bee colony algorithm for
MPPT photovoltaic system under partial shading condition," International Journal of Power Electronics and Drive Systems, vol. 8, no. 2, p. 647, 2017.

[13] Y. Shaiek, M. B. Smida, A. Sakly, and M. F. Mimouni, "Comparison between conventional methods and GA approach for maximum power point tracking of shaded solar PV generators," Solar energy, vol. 90, pp. 107-122, 2013.

[14] J. Qi, Y. Zhang, and Y. Chen, "Modeling and maximum power point tracking (MPPT) method for PV array under partial shade conditions," Renewable Energy, vol. 66, pp. 337-345, 2014.

[15] Y. Liu, D. Xia, and Z. He, "MPPT of a PV system based on the particle swarm optimization," in 2011 4th International Conference on Electric Utility Deregulation and Restructuring and Power Technologies (DRPT), 2011: IEEE, pp. 1094-1096.

[16] R. B. Koad, A. F. Zobaa, and A. El-Shahat, "A novel MPPT algorithm based on particle swarm optimization for photovoltaic systems," IEEE Transactions on Sustainable Energy, vol. 8, no. 2, pp. 468-476, 2016.

[17] K. Sundareswaran, V. Vigneshkumar, P. Sankar, S. P. Simon, P. S. R. Nayak, and S. Palani, "Development of an improved P\&O algorithm assisted through a colony of foraging ants for MPPT in PV system," IEEE Transactions on Industrial Informatics, vol. 12, no. 1, pp. 187-200, 2015.

[18] A. Fathy and H. Rezk, "A novel methodology for simulating maximum power point trackers using mine blast optimization and teaching learning based optimization algorithms for partially shaded photovoltaic system," Journal of Renewable and Sustainable Energy, vol. 8, no. 2, p. 023503, 2016.

[19] H. Rezk and A. Fathy, "Simulation of global MPPT based on teaching-learning-based optimization technique for partially shaded PV system," Electrical engineering, vol. 99, pp. 847-859, 2017.

[20] N. Kumar, I. Hussain, B. Singh, and B. K. Panigrahi, "MPPT in dynamic condition of partially shaded PV system by using WODE technique," IEEE Transactions on Sustainable Energy, vol. 8, no. 3, pp. 1204-1214, 2017.

[21] N. Kumar, I. Hussain, B. Singh, and B. K. Panigrahi, "Rapid MPPT for uniformly and partial shaded PV system by using JayaDE algorithm in highly fluctuating atmospheric conditions," IEEE Transactions on Industrial Informatics, vol. 13, no. 5, pp. 2406-2416, 2017.

[22] R. Sridhar, S. Jeevananthan, S. S. Dash, and P. Vishnuram, "A new maximum power tracking in PV system during partially shaded conditions based on shuffled frog leap algorithm," Journal of Experimental \& Theoretical Artificial Intelligence, vol. 29, no. 3, pp. 481-493, 2017.

[23] M. Mao, L. Zhang, Q. Duan, O. Oghorada, P. Duan, and B. Hu, "A two-stage particle swarm optimization algorithm for MPPT of partially shaded PV arrays," International Journal of Green Energy, vol. 14, no. 8, pp. 694-702, 2017.

[24] Y. Ma, X. Zhou, Z. Gao, and T. Bai, "Summary of the novel MPPT (maximum power point tracking) algorithm based on few intelligent algorithms specialized on tracking the GMPP (global maximum power point) for photovoltaic systems under partially shaded conditions," in 2017 IEEE International Conference on Mechatronics and Automation (ICMA), 2017: IEEE, pp. 311-315.

[25] R. Nagarajan, R. Yuvaraj, V. Hemalatha, S. Logapriya, A. Mekala, and S. Priyanga, "Implementation of PV-based boost converter using PI controller with PSO algorithm," International Journal of Engineering And Computer Science (IJECS), vol. 6, no. 3, pp. 20479-20484, 2017.

[26] V. Khanna, B. Das, D. Bisht, and P. Singh, "A three diode model for industrial solar cells and estimation of solar cell parameters using PSO algorithm," Renewable Energy, vol. 78, pp. 105-113, 2015.

[27] O. S. Elazab, H. M. Hasanien, I. Alsaidan, A. Y. Abdelaziz, and S. Muyeen, "Parameter estimation of three diode photovoltaic model using grasshopper optimization algorithm," Energies, vol. 13, no. 2, p. $497,2020$.

[28] N. M. A. A. Shannan, N. Z. Yahaya, and B. Singh, "Single-diode model and two-diode model of PV modules: A comparison," in 2013 IEEE International Conference on Control System, Computing and Engineering, 2013: IEEE, pp. 210-214.

[29] F. Masmoudi, F. B. Salem, and N. Derbel, "Single and double diode models for conventional mono-crystalline solar cell with extraction of internal parameters," in 2016 13th International Multi-Conference on Systems, Signals \& Devices (SSD), 2016: IEEE, pp. 720-728. 
[30] U. Yilmaz, O. Turksoy, and A. Teke, "Improved MPPT method to increase accuracy and speed in photovoltaic systems under variable atmospheric conditions," International Journal of Electrical Power \& Energy Systems, vol. 113, pp. 634-651, 2019.

[31] X. H. Nguyen and M. P. Nguyen, "Mathematical modeling of photovoltaic cell/module/arrays with tags in Matlab/Simulink," Environmental Systems Research, vol. 4, no. 1, pp. 1-13, 2015.

[32] G. Singh and S. Kundu, "An efficient DC-DC boost converter for thermoelectric energy harvesting," AEU-International Journal of Electronics and Communications, vol. 118, p. 153132, 2020.

[33] N. Chatrenour, H. Razmi, and H. Doagou-Mojarrad, "Improved double integral sliding mode MPPT controller based parameter estimation for a stand-alone photovoltaic system," Energy Conversion and Management, vol. 139, pp. 97-109, 2017.

[34] R. Suganya, M. V. Rajkumar, and P. Pushparani, "Simulation and Analysis of Boost Converter with MPPT for PV System using Chaos PSO Algorithm," Int. J. Emerg. Technol. Eng. Res, vol. 5, pp. $97-$ $105,2017$.

[35] S. Pant and R. Saini, "Comparative study of MPPT techniques for solar photovoltaic system," in 2019 International Conference on Electrical, Electronics and Computer Engineering (UPCON), 2019: IEEE, pp. 1-6.

[36] M. M. Iqbal and K. Islam, "Design and simulation of a PV System with battery storage using bidirectional DC-DC converter using Matlab Simulink," International Journal of scientific \& Technology research, vol. 6, no. 07, 2017.

[37] P. S. Gavhane, S. Krishnamurthy, R. Dixit, J. P. Ram, and N. Rajasekar, "EL-PSO based MPPT for solar PV under partial shaded condition," Energy Procedia, vol. 117, pp. 1047-1053, 2017.

[38] M. Sarvi, S. Ahmadi, and S. Abdi, "A PSO-based maximum power point tracking for photovoltaic systems under environmental and partially shaded conditions," Progress in Photovoltaics: Research and Applications, vol. 23, no. 2, pp. 201-214, 2015.

[39] H. Rezk, A. Fathy, and A. Y. Abdelaziz, "A comparison of different global MPPT techniques based on meta-heuristic algorithms for photovoltaic system subjected to partial shading conditions," Renewable and Sustainable Energy Reviews, vol. 74, pp. 377-386, 2017.

[40] S. Mohanty, B. Subudhi, and P. K. Ray, "A new MPPT design using grey wolf optimization technique for photovoltaic system under partial shading conditions," IEEE Transactions on Sustainable Energy, vol. 7, no. 1, pp. 181-188, 2015.

[41] S. Lyden and M. E. Haque, "A simulated annealing global maximum power point tracking approach for PV modules under partial shading conditions," IEEE Transactions on Power Electronics, vol. 31, no. 6 , pp. 4171-4181, 2015.

[42] K. Sundareswaran, P. Sankar, P. S. R. Nayak, S. P. Simon, and S. Palani, "Enhanced energy output from a PV system under partial shaded conditions through artificial bee colony," IEEE transactions on sustainable energy, vol. 6, no. 1, pp. 198-209, 2014.

[43] K. Sundareswaran, S. Peddapati, and S. Palani, "MPPT of PV systems under partial shaded conditions through a colony of flashing fireflies," IEEE transactions on energy conversion, vol. 29, no. 2, pp. 463-472, 2014

\section{Title Arabic:}

$$
\begin{aligned}
& \text { تحسين أداء خوارزمية أسراب الطيور لتتبع أقصى قدرة للخلايا } \\
& \text { الكهروضوئية في الظروف العادية و التظليل الجزئي الطئي ألئي }
\end{aligned}
$$

\section{Arabic Abstract:}

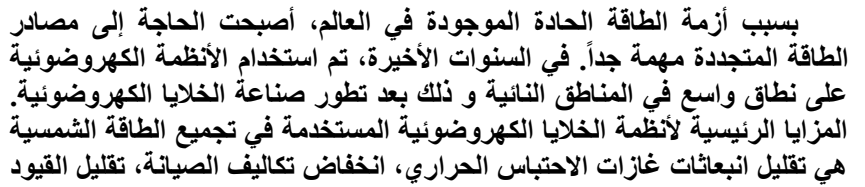

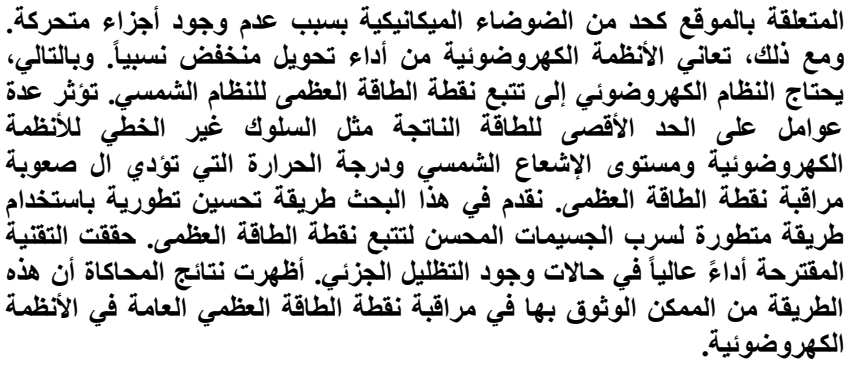

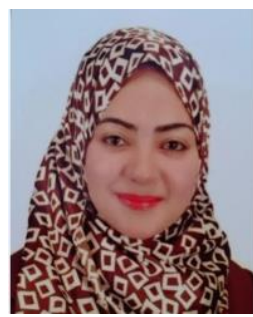

Hend Samir is M.SC Student at the Department of Computers Engineering and Control Systems, Faculty of Engineering, Mansoura University. Her area of interests is adaptive, optimal and intelligent control systems.

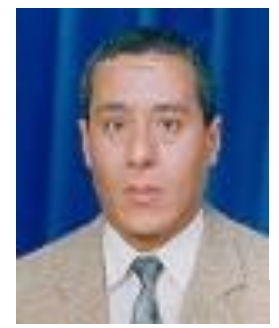

Mohamed S. M. ELKsas is Associate Professor of control engineering, faculty of engineering, Mansoura University. Currently in Delta University. His area of interests is adaptive and optimal systems.

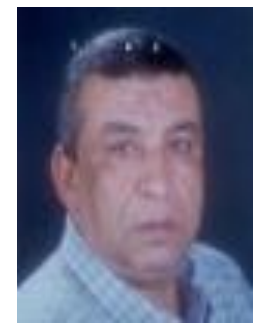

Sabry F. Saraya, Associate Professor of control engineering, faculty of engineering, Mansoura University. His area of interests is adaptive, optimal and intelligent control systems.

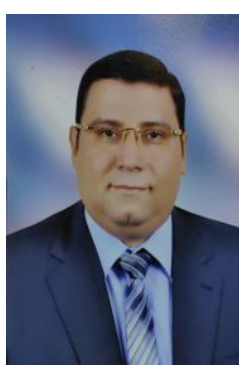

Mohamed M. Abdelsalam is an Assistant Professor at computers engineering and control systems department in Faculty of Engineering, Mansoura University. His research interests include image processing, adaptive control, artificial intelligent, expert systems, computer networks and data mining. 